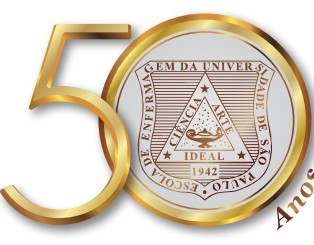

\title{
Uncoordinated psychosocial network compromising the integrality of care*
}

\author{
Desarticulação da rede psicossocial comprometendo a integralidade do cuidado \\ Desarticulación de la red psicosocial comprometiendo la integralidad del cuidado
}

Maria de Fátima Alves Aguiar Carvalho¹, Edméia de Almeida Cardoso Coelho², Jeane Freitas de Oliveira², Rosália Teixeira de Araújo ${ }^{3}$, Andiara Rodrigues Barros ${ }^{4}$

How to cite this article:

Carvalho MFAA, Coelho EAC, Oliveira JF, Araújo RT, Barros AR. Uncoordinated psychosocial network compromising the integrality of care. Rev Esc Enferm USP. 2017;51:e03295. DOI: http://dx.doi.org/10.1590/S1980-220X2016040703295

* Extracted from the thesis: "Integralidade do cuidado na atenção psicossocial”, Programa de Pós-Graduação em Enfermagem,

Universidade Federal da Bahia, 2016.

${ }^{1}$ Universidade Federal do Vale do São Francisco, Colegiado de Enfermagem, Petrolina, PE, Brazil.

${ }^{2}$ Universidade Federal da Bahia, Escola de Enfermagem, Salvador, BA, Brazil.

${ }^{3}$ Universidade Estadual do Sudoeste da Bahia, Jequié, BA, Brazil.

${ }^{4}$ Universidade Federal da Bahia, Programa de Pós-Graduação em Enfermagem, Salvador, BA, Brazil.
Corresponding author:

Maria de Fátima Alves Aguiar Carvalho

Universidade Federal do Vale do São Francisco

Alameda das Hortênsias, 91

Condomínio Sol Nascente II

CEP 56332-760 - Petrolina, PE, Brazil

fatimaaguiar@hotmail.com.br

\section{ABSTRACT}

Objective: To discuss the lack of coordination in the Psychosocial Care Network from the conception of professionals of a Psychosocial Care Center for Alcohol and Drugs (Portuguese acronym: CAPSad). Method: Qualitative study conducted with professionals from a CAPSad unit. The empirical material was produced through two reflection workshops focused on care experiences, and analysis using the discourse analysis technique. The category of analysis was integrality. Results: Nine professionals participated in the study. All of them reported being part of a disarticulated service network, in disagreement with principles of the national mental health policy, which directly affects the resolution of care provided in the unit. Conclusion: The operating logic in the Psychosocial Care Network tends to reduce the care of drug users to the CAPSad assistance, hence compromising the integrality of care.

\section{DESCRIPTORS}

Mental Health Services; Integrality in Health; Drug Users; Health Personnel; Patient Care Team; Psychiatric Nursing. 


\section{INTRODUCTION}

Brazil is recognized internationally as a reference for the development of a Mental Health Policy based on overcoming the mental asylum by replacing the psychiatric hospital with a community-based and territorial network, centered on guaranteeing outpatient care freedom and exercising citizenship ${ }^{(1-2)}$.

The Psychiatric Reform seeks to ensure extra-hospital services to care for people with mental disorders and drug users. This change represents progress in relation to the assistance before the reform provided basically in psychiatric hospitals ${ }^{(3)}$.

The contributions of the first Psychosocial Care Centers (Portuguese acronym: CAPS/NAPS) are considered a symbol for the construction of psychosocial care practices that go beyond the reformed psychiatry. From Law 10.216/2001 of the Reform, CAPS are considered strategic mental health services because they are organized into multidisciplinary and complementary teams, and seek to meet people's different needs in their treatment and rehabilitation process ${ }^{(4)}$.

Psychosocial Care is a public policy demarcating knowledge and practices crossed by an emancipatory ethical-political ideology that replaces the organicist and medical-centered psychiatry still prevailing in current practices. Positive experiences of the CAPS consider that mental health issues are not restricted to psychiatry, but influenced by social, political and historical aspects, in the relationship with family, community and society, and result in integral care guided by the Policy of Harm Reduction ${ }^{(3)}$.

The integrality of care to drug users presupposes an expansion of the Psychosocial Care Network (Portuguese acronym: RAPS) in coordination with professionals' actions and a comprehensive view that includes user embracement. Therapeutic projects are designed based on users' needs and the availability of listening, hence translating into the consolidation of bonds, accountability and access to the different care levels ${ }^{(4)}$.

The RAPS is designed to meet demands arising from mental disorders or use of alcohol and other drugs from primary care, specialized services (CAPS and others), general hospitals with reference beds for mental health, emergency/ urgency services, generation of income and work, community centers and other alternatives in the territory, depending on the reality of each municipality ${ }^{(5)}$.

In the national scenario, the RAPS has more than 2,300 CAPS, where more than 30,000 professionals work, with 700 Therapeutic Residential Services, 39,228 Family Health Strategy (FHS) teams, 3,898 Family Health Support Centers, and 129 teams from Clinics on the street (Portuguese acronym: $\mathrm{CnR}$ ). These agencies ensure the expansion and qualification of actions in mental health, alcohol and other drugs in primary care and general hospital care, and the inclusion of the Emergency Care Network ${ }^{(6)}$.

However, this network must be very well articulated to be efficient. A service constantly needs the others given the complex demand for including socially excluded people such as users of alcohol and other drugs. Furthermore, the services forming the network should dialogue in the same logic of Harm Reduction.

Taking Harm Reduction as a guideline for mental health care assumes that not all drug experiments are harmful; not all people who have harmful relationships with drugs want to stop using them; the harm produced can be of several orders, and it demands actions to address these singular diversities by establishing that stop using drugs as therapeutic goal is a possibility, and not the only goal for all people ${ }^{(7)}$.

International research on harm reduction reports that although 97 countries support the approach explicitly through official policies, implementation of programs has been slow in practice, and many remain in the pilot phase ${ }^{(8)}$.

In Brazil, this experience has been occurring gradually with the articulation between harm reduction, mental health and family health strategy. The proximity of psychosocial care with family and community allows the FHS to be the main partner of the CAPS, since through primary care this strategy has greater insertion power in the territory. The partnership between CAPS and FHS strengthens the care network and creates new possibilities in the care of people with disorders resulting from drug use, and facilitates the transit in people's subjective territory by establishing relationships of trust, availability and affection ${ }^{(9)}$.

Studies show that mental health care practice is not performed in a network, but rather centralized in the CAPS because of lack of articulation, communication, an organizational flow of services, and the need for matrix support for mental health work in Primary Care ${ }^{(10)}$.

As professionals who experience the difficulties of interaction of these care spaces, we affirm that primary care cannot always deal with specificities involved in drug use. There is lack of infrastructure in health units and of professional qualification, which hinders the development of integral care. These difficulties affect the CAPSad, where the working dynamics presupposes the partnership with the network that in turn provides support at primary level.

This study was developed as part of a wider research in order to offer elements to explain the reality and point out ways for the interaction between the RAPS at its different levels. The objective was to discuss the lack of coordination in the RAPS from the conception of CAPSad professionals.

\section{METHOD}

This is a qualitative study and the category of analysis was integrality. It was conducted in the Psychosocial Care Center for Alcohol and other Drugs (Portuguese acronym: CAPSad) of the sub-middle region of São Francisco, state of Pernambuco, Brazil. The research locus service was implemented in May 2006, with the purpose of developing individual and collective care actions, inside and outside the institutional space. It was intended for people with problematic use of drugs aged over 18 years and their families in a proposal based on the harm reduction policy. Work hours are from Monday to Friday, from 8:00 am to 5:00 pm and there are 198 registered people.

Data were produced in July and August 2015. The multi/ inter-professional team had 14 workers, six of which were 
from the following health professional categories: social worker, nursing, medicine, pharmacy and psychology. The rest were professionals working in reception, concierge, kitchen and general services.

Integrality is expressed in the interdisciplinary characteristics of health practices, based on values of guarantee of autonomy, on the exercise of solidarity, and the recognition of the freedom to choose the desired care and health. Far beyond the identification of demands, it involves understanding people's needs sometimes hidden by the face of the disease ${ }^{(10)}$.

In Mental Health, the format of the RAPS is consolidated to the perspective of integrality, and aims at integrating the services forming it, as well as the interdependence of those involved, with the understanding that no service has all the necessary resources and skills for solution of demands to result in quality, efficiency, effectiveness and resolution ${ }^{(11)}$.

Integrality is embodied through health practices that certify resolutive actions at the various levels of care by paying attention to people's singularities. In this sense, care is provided with users' embracement, sensitive listening, bonding and accountability, and appreciation of the influence of the context in which needs are generated ${ }^{(12-13)}$.

The inclusion criteria for participants were: to act in the CAPSad proposed as a research site for at least five months and not being on medical leave or bonus leave. The time was established because it was considered appropriate for the correct adjustment to the service routine, and to ensure the participation of all professional categories (a professional had been working within the indicated minimum time).

In order to meet the demands of the object of this study, were considered the statements of nine professionals who met the established criteria. Health professionals: a social worker, a nurse, a pharmacist, a physician, two psychologists (one of them also worked as coordinator). Professionals from other areas: a receptionist, a chef and a doorman. The majority were single, average age of 38 years, ranging from 24 to 53 years old. The time working in the CAPSad was between five months and nine years, and mean time of two years and six months. The physician's residency course was in psychiatry, with specialization in chemical dependency. One of the psychologists had a master's degree in Collective Health. The other professionals started working in the service without any prior experience or qualification in the area, and they attended short courses on alcohol and other drugs while working.

The empirical material was produced by means of a reflection workshop, which is considered a privileged ethical-political tool, since it allows the creation of dialogical spaces of symbolic exchanges, and welcomes and sensitizes participants to the theme by allowing a variety of versions and meanings about the theme ${ }^{(14)}$.

There were two reflection workshops entitled 'Care in the CAPSad' and 'Rescuing care in the CAPSad'. The meetings happened in a space intended for group activities in the service and were conducted by a coordinator/facilitator and a collaborator/observer.
The first workshop was developed from questions that generated reflection and discussion: Who is the person who uses the CAPSad services? Which experiences have I had with this person since I started working here? Have these care experiences addressed users' needs?

The content of the previous meeting was resumed in the second workshop. Afterwards, professionals were asked to identify positive and negative aspects in the care process in the CAPSad, based on the dynamics in which they symbolically identified these aspects and listed them for discussion.

The meetings lasted two hours on average, and followed the stages of presentation and integration; development of the theme; socialization of experiences; synthesis; evaluation and recreation/relaxation. Workshops were recorded, photographed and later transcribed in full for analysis and discussion. From the empirical material produced, in this article was explored the category that gave title to it.

The empirical material was analyzed by the discourse analysis technique proposed by Fiorin. According to the author, the discourse represents a social position, and its ideological representations are materialized in language. As the discourse is analyzed, is revealed the worldview of the subject inscribed in the discourse. The operationalization of the technique involved the following steps: reading the material for identification of concrete (figures) and abstract (themes) elements; understanding of partial themes; grouping of partial themes into blocks of meanings; formulation of subcategories; and formulation of central empirical categories ${ }^{(15)}$.

All the precepts of resolution 466/2012 of the National Health Council regarding ethical standards of research involving human beings were respected. Participation was free and voluntary after signing the Informed Consent form. Prior approval was obtained from the Committee of Ethics and Deontology in Studies and Research of the Universidade Federal do Vale do São Francisco, issued on October 14, 2014, under opinion number 0008/141014 CEDEP/UNIVASF. To ensure participants' anonymity, we chose not to identify the municipality and used the professional category in the statements.

\section{RESULTS}

Nine professionals participated in the study. They reported being inserted in a disarticulated service network, that is in disagreement with the principles of the National Mental Health Policy. The policy advocates an open network with connectivity in the care points, dialogue between professionals, and shared care:

In order to function, the CAPS must be articulated with other services. We deal with a network in which communication and the way of acting are insufficient, and we try to establish this link (...) with the health care network itself. In addition, we have to articulate with social services, with education, but sometimes within our own health network we cannot communicate (psychologist 2).

Another difficulty is the uncoordinated network, the health network itself (...) for example, today we are trying to coordinate 
with another service, see what's best for the patient and we are not being able to talk (nurse).

According to professionals' reports, the service network is inefficient and compromises the principles of the policy and imposes barriers to the continuity of care, which becomes clear in the testimonials:

These difficulties denounce the inefficiency of the network, the Family Health Program, and of social services, we feel that the CAPS alone without these partnerships is even more difficult (...) there must be continuity of this care to be complete, we often need other services and we don't have that support (psychologist 1).

We conduct the follow-up treatment but sometimes, later on, there is no continuity of care, but when it comes to our service, our professionals, we are meeting this demand (social worker).

The care provided by professionals is differentiated from other services, with user embracement and valuation of demands that do not fit the model of conduct complaint, and suffers ruptures in cases of referrals to other institutions, as expressed below:

In the same way that patients get here and are welcomed and well treated by the team, they expect to have the style of care they have here in other units. In other services it is not so, there are many difficulties, even in hospitals, some health units work with a very different reality (physician).

We do the best, but we make referrals, and in the other service the patient is not well received, they always complain about that (...) or we do not have a return, that makes it very difficult, this lack of articulation (nurse).

One of the consequences of the RAPS inoperation is the longer length of stay in the CAPSad, which leads to the chronification of users:

When patients don't have any support, there's a strong possibility they won't motivate themselves, these patients need to stay here longer, then, they become chronic patients (...) you work in order that patients remains outside, but they don't stabilize, then there's always this movement of being near the CAPS, since they find the support they need in the institution, and don't find it anywhere else (...) the more support they have, from family, friends, the service network the less they'll need it from here, hence not leading to chronification (physician).

Sometimes people come here, spend a morning or two, three times a week, or even every day, but what we're doing for them can be undone 'cause it's very different outside, and often they don't have support (receptionist).

It's very difficult outside, they don't have any support, it's hard to encourage these people to carry on fighting in life, so they end up staying here (pharmacist).

\section{DISCUSSION}

The starting point is the understanding of the care network as a set of services linked to each other by common objectives, with articulated, cooperative and interdependent actions, with the aim to offer integral and continuous care to a given population ${ }^{(16)}$.
The network constitution requires more than services that meet the population demands. The existence of dialogue between its integrating services is essential, because the solidity of the network structure is based on interpersonal dialogical relations ${ }^{(16)}$. These characteristics are consistent with the sharing of the Psychiatric Reform ideas and with a critical, reflexive, creative and integral daily practice. However, this idea is not confirmed in the statements of professionals, who mention the lack of coordination in the RAPS and question the way in which its organization is put into practice.

RAPS of the municipality where this study was conducted has a variety of services: a CAPS II, a CAPSad II (in transition to CAPSad 24 hours during the study period), a CAPSi (CAPS for children), a street clinic team (CnR), and six beds in the Hospital Reference Service. According to its guidance policies, these services should be part of primary care and specialized care, such as SAMU (Brazilian emergency service) and polyclinics in an attempt to ensure the integrality of care.

However, professionals' statements show a different reality from that expected from an integrated, articulated and effective network in its different care points. In the CAPSad service with user embracement and accountability, there is discontinuity of care in cases of referrals to other services. Users have their expectations frustrated when the net where they were inserted while attending the CAPSad service is broken.

The production of care in the territory covered by the RAPS involves inter/intra-personal and inter/intra-institutional relationships. Therefore, such production must take into account the health services and community network (churches, schools, justice) mediated by communication channels in a partnership relationship and the addition of important points of constitution of care ${ }^{(17)}$.

The logic in the site of our study operates with tendency to reduce care to users to the connection with the CAPSad. The services work disconnected, without communication with other spheres like education, justice, school and social assistance, and even other health services, making care in the territory difficult.

In this sense, territory is understood as the place where community life takes place. It refers to the space where the whole network of existential relations is established, where everyday life happens by giving meaning to the inhabited place. Thus, for materialization of territorial care, all components, knowledge and forces of the community should be used, because such community has demands, proposes solutions and builds common goals ${ }^{(18)}$.

The proposal of Psychosocial Care is guided by integrality. From this perspective, team work must occur collectively and demand commitment from all the involved, professionals, service users, families and the community. It is defined as the clinic of knowing/doing that considers people's life history in the territory, their social, affective and family relationships. Therefore, focus is not on the disorder, but rather on people and their social context ${ }^{(4)}$.

According to the statements, there are no concrete actions in the network of the studied municipality in this sense, which demonstrates the lack of clarity regarding the RAPS coordination. Our study corroborates a study conducted in 
Porto Alegre/Rio Grande do Sul state in which was found that the CAPS II includes in the intensive mode people who do not need this type of care, because they perceive a lack in the 'network' since there are no services to support 'unserved' people. To a certain extent, this contributes to the centralization of the CAPS at a moment when this service is responsible for demands that should be referred to other levels of health care ${ }^{(19)}$.

Other studies indicate that people who could be accommodated in Primary Care end up being referred to the CAPS and/or other specialized services and staying in them longer than they should ${ }^{(4)}$.

Professionals participating in our study reported that users remain indefinitely in the CAPSad due to lack of support in the health network. They expressed concern about the institutionalization and "veiled" chronification of these people. In a certain way, this reproduces the asylum model, and is contrary to the principles of the Psychiatric Reform, which invests in deinstitutionalization, reconstruction of autonomy and citizenship.

In a sense, people with drug use disorders see the CAPSad not only as a therapeutic space, but also as the only alternative for embracement of affective needs and social and symbolic exchanges. Without guarantee of social reintegration and continuity in Primary Care, they become dependent on CAPSad care, which interferes with the reconstruction of their autonomy and citizenship.

The exit of the CAPSad does not mean lack of assistance, on the contrary, it is a moment when other services of the network, especially Primary Care, must show the capacity to welcome and support people and their families within their territory. At this point, there must be a discussion on the benefits of leaving the service by showing users this will not be a loss, but the achievement of another stage of treatment that will enable the construction of new relationships with other institutions and people ${ }^{(4)}$.

The strategy proposed to ensure support to these people is the reinforcement of Matrix Support in the FHS. It can alleviate problems of articulation of the municipal RAPS and organize professionals' work process by favoring openness to the territory in a different logic from that of referrals.

Matrix-based strategies advocate the sharing of care between the reference and support teams, valorization of knowing/doing spaces by promoting the co-responsibility of professionals/users. In the medium and long term, Primary Care professionals are expected to meet the demands in order to avoid unnecessary referrals to the CAPS and other specialized services, increasing the network resolving capacity ${ }^{(19)}$.

The reality presented in the professionals' statements showed the opposition between what is proposed by the Reform and the concrete reality in the Mental Health network of the studied municipality. The results reinforce how important is the responsibility of both Primary Care and other services that form the RAPS regarding the care of people with problems resulting from alcohol and other drugs since the CAPSad alone cannot meet the demands.

The uncoordinated network demonstrates the historical reference of mental health care represented by a model that isolates those included in it and in need of care. This permanence generates contradictions with the National Mental Health Policy that proposes to overcome what is instituted and in this study, sees the CAPSad as a space of possibilities.

\section{CONCLUSION}

In the CAPSad locus of this study, professionals refer to a care put into practice through user embracement, sensitive listening, bonding and accountability, i.e., dimensions of integrality. However, the reach of integrality is compromised because of the lack of coordination and inefficiency in the RAPS that directly affects the resolution of the care provided.

There is disagreement between the proposal of the National Mental Health Policy and the psychosocial network reality in the municipality, where the operating logic tends to reduce the care of people with abusive use of drugs to the link with the CAPSad service.

The testimonies show the difficulties and obstacles for people's access to other services, and assistance is restricted to the CAPSad. In practice, there are no inter-institutional partnerships to share the demands, impacting on the team's work process.

We emphasize that issues related to drug abuse or dependence are not static, but move along their own paths and indicate the types of services needed. Primary Care, especially the FHS, which would be the main link with the CAPS, is not presented by the CAPSad team as a space for the embracement of drug users. This is a concerning scenario because the FHS together with the CAPS, is an instrument to guide the network dynamics, besides being the space towards where the movement of deinstitutionalization and decentralization of mental health care is directed.

The lack of coordination between services leads to the care centralization in the CAPSad, which in turn implies indeterminate length of stay of users given the lack of support in the services for continuity of care. In a veiled way, this leads to the institutionalization and chronification of processes that could be abbreviated with effective interaction between care spaces. This ratifies the hegemonic practice of producing health and repeats the actions of traditional psychiatry, which is in clear contradiction with the model of care built to break with this logic.

The broadness and complexity of the RAPS issues show the need to integrate the CAPSad into Primary Care services with the FHS as one of the main articulators of this process. This way, the proposed care model will become decentralized from the CAPS and offer services in the territory near people's homes, therefore, relieving the RAPS service. For integrality effectiveness, there must be continuity of care with network articulation, and team's resolutive actions guided by user embracement, information, listening, establishment of bonds and accountability.

Finally, we conclude it is essential to implement and/ or even shake this network in order to make its proposals efficient. The studied reality showed that the quantity and variety of assistance services offered at the different levels of care in the municipality are sufficient to attend drug 
users. However, without a doubt, there must be activation of networks of dialogue and planning of flows with resolutive and complementary actions, governed by user embracement, sensitive listening, bonding and accountability, which are also indispensable aspects for the quality of care when it comes to integrality.

\section{RESUMO}

Objetivo: Discutir a desarticulação da Rede de Atenção Psicossocial a partir da concepção de profissionais de um Centro de Atenção Psicossocial Álcool e Drogas. Método: Estudo qualitativo, realizado com profissionais de um CAPSad. O material empírico foi produzido por meio de duas oficinas de reflexão, com foco nas experiências de cuidado vivenciadas, e analisado pela técnica de análise de discurso, tendo a integralidade como categoria de análise. Resultados: Participaram do estudo nove profissionais. Todos referiram estar inseridos em uma rede de serviço desarticulada, destoante dos princípios da Política Nacional de Saúde Mental, que repercute diretamente na resolutividade do cuidado prestado na unidade. Conclusão: A lógica operada na Rede de Atenção Psicossocial tende a reduzir o cuidado de pessoas que usam drogas ao CAPSad, comprometendo a integralidade do cuidado.

\section{DESCRITORES}

Serviços de Saúde Mental; Integralidade em Saúde; Usuários de Drogas; Pessoal de Saúde; Equipe de Assistência ao Paciente; Enfermagem Psiquiátrica.

\section{RESUMEN}

Objetivo: Discutir la desarticulación de la Red de Atención Psicosocial a partir de la concepción de profesionales de un Centro de Atención Psicosocial Alcohol y Drogas. Método: Estudio cualitativo, realizado con profesionales de un CAPSad (Centro de Atención Psicosocial Alcohol y Drogas). El material empírico fue producido mediante dos talleres de reflexión, con foco en las experiencias de cuidado vividas y analizado por la técnica de análisis de discurso, teniendo la integralidad como categoría de análisis. Resultados: Participaron en el estudio nueve profesionales. Todos relataron estar insertados en una red de servicio desarticulada, discordante de los principios de la Política Nacional de Salud Mental, que repercute directamente en la resolutividad del cuidado prestado en la unidad. Conclusión: La lógica operada en la Red de Atención Psicosocial tiende a reducir el cuidado de personas drogadictas al CAPSad, comprometiendo la integralidad del cuidado.

\section{DESCRIPTORES}

Servicios de Salud Mental; Integralidad en Salud; Consumidores de Drogas; Personal de Salud; Grupo de Atención al Paciente; Enfermería Psiquiátrica.

\section{REFERENCES}

1. Desviat M. Panorama internacional de la reforma psiquiátrica. Ciênc Saúde Coletiva [Internet]. 2011 [citado 2015 Dez. 05];16(12):4615-21. Disponible en: http://www.scielo.br/pdf/csc/v16n12/10.pdf

2. Calouste Gulbenkian Fundation; Nova University of Lisboa, Faculty of Medical Sciences, Department of Mental Health. Gulbenkian Global Mental Health Platform [Internet] Lisboa, Portugal, 2015 [cited 2016 Feb 28]. Available from: http://www.globalmentalhealth.org/ sites/default/files/docs/GulbMHPlatf.pdf

3. Costa-Rosa A. Atenção psicossocial além da Reforma Psiquiátrica: contribuições a uma Clínica Crítica dos processos de subjetivação na Saúde Coletiva. São Paulo: Ed. UNESP; 2013.

4. Oliveira RF, Andrade LOM, Goya N. Acesso e integralidade: a compreensão dos usuários de uma rede de saúde mental. Ciênc Saúde Coletiva [Internet]. 2012 [citado 2016 set. 10];17(11):3069-78. Disponível em: http://www.scielo.br/pdf/csc/v17n11/v17n11a22.pdf

5. Mielke FB, Kantorski LP, Olschowsky A, Jardim VMR. Características do cuidado em saúde mental em um CAPS na perspectiva dos profissionais. Trab Educ Saúde [Internet]. 2011 [citado 2016 set 6];9(2):265-76. Disponível em: http://www.scielo.br/pdf/tes/ v9n2/06.pdf

6. Brasil. Ministério da Saúde; Portal da Saúde. Rede de Atenção Psicossocial (RAPS) [Internet]. Brasília; 2016 [citado 2016 ago. 16]. Disponível em: http://dab.saude.gov.br/portaldab/smp_ras.php?conteudo=rede_psicossocial

7. Souza TP, Carvalho SR. Reduzindo danos e ampliando a clínica: desafios para a garantia do acesso universal e confrontos com a internação compulsória. Rev Polis Psique. 2012 [citado 2016 set. 18];2(3):37-58. Disponível em: http://seer.ufrgs.br/index.php/PolisePsique/article/ view/40319/25628

8. Beg M, Strathdee AS, Kazatckine M. State of the art Science addressing injecting drug use, HIV and harm reduction. Int J Drug Policy [Internet]. 2015 [cited 2014 May 30];26 Suppl 1:S1-4. Available from: http://www.sciencedirect.com/science/article/pii/ S0955395914003326?via\%3Dihub

9. Cortes LF, Terra MG, Pires FB, Heinrich J, Machado KL, Weiller TH, et al. Atenção a usuários de álcool e outras drogas e os limites da composição de redes. Rev Eletr Enf [Internet]. 2014 [citado 2016 out. 12];16(1):84-92. Disponível em: https://www.fen.ufg.br/fen_revista/ v16/n1/pdf/v16n1a10.pdf

10. Viegas SMF, Penna CMM. A construção da integralidade no trabalho cotidiano da equipe saúde da família. Esc Anna Nery [Internet]. 2013 [citado 2016 ago. 10];17(1):133-41. Disponível em: http://www.scielo.br/pdf/ean/v17n1/19.pdf

11. Brito MJM, Andrade AM, Caçador BS, Freitas LFC, Penna CMM. Home care in the structuring of the healthcare network: following the paths of comprehensiveness. Esc Anna Nery [Internet]. 2013 [cited 2016 Jan 23];17(4):603-10. Available from: http://www.scielo.br/pdf/ ean/v17n4/en_1414-8145-ean-17-04-0603.pdf

12. Coelho EAC, Andrade MLS, Vitoriano LVT, Souza JJ, Silva DO, Gusmão MEN, et al. Association between unplanned pregnancy and the socioeconomic context of women in the area of family health. Acta Paul Enferm [Internet]. 2012 [cited 2016 Feb 15];25(3):415-22. Available from: http://www.scielo.br/pdf/ape/v25n3/en_v25n3a15.pdf 
13. Mororó MEML, Colvero LA, Machado AL. The challenges of comprehensive care in a Psychosocial Care Center and the development of therapeutic projects. Rev Esc Enferm USP [Internet]. 2011 [cited 2016 July 20];45(5):1167-72. Available from: http://www.scielo.br/pdf/ reeusp/v45n5/en_v45n5a20.pdf

14. Spink MJ, Menegon VM, Medrado B. Oficina como estratégia de pesquisa: articulações teórico-metodológicas e aplicações ético-políticas. Rev Psicol Soc [Internet]. 2014 [citado 2016 abr. 25];26(1):32-42. Disponível em: http://www.ufrgs.br/seerpsicsoc/ojs2/index.php/ seerpsicsoc/article/view/3695/2311

15. Fiorin JL. Linguagem e ideologia. São Paulo: Ática; 2011.

16. Mendes EV. As redes de atenção à saúde. Ciênc Saúde Coletiva [Internet]. 2010 [citado 2016 abr. 11];15(5):2297-305. Disponível em: http://www.scielo.br/pdf/csc/v15n5/v15n5a05.pdf

17. Dutra VFD, Oliveira RMP. Revisão integrativa: as práticas territoriais de cuidado em saúde mental. Aquichán [Internet]. 2015 [citado 2016 mar 10];15(4):529-40. Disponível em: http://aquichan.unisabana.edu.co/index.php/aquichan/article/view/3756/pdf

18. Gazignato ECS, Castro e Silva CR. Saúde mental na atenção básica: o trabalho em rede e o matriciamento em saúde mental na Estratégia de Saúde da Família. Saúde Debate [Internet]. 2014 [citado 2016 maio 02];38(101):296-304. Disponível em: http://www.scielo.br/pdf/ sdeb/v38n101/0103-1104-sdeb-38-101-0296.pdf

19. Scheibelb A, Ferreira LH. Acolhimento no CAPS: reflexões acerca da assistência em saúde mental. Rev Baiana Saúde Pública [Internet]. 2011 [citado 2016 jan 20]; 35(4):966-83. Disponível em: http://files.bvs.br/upload/S/0100-0233/2011/v35n4/a2821.pdf 